\title{
Diaminopimelic Acid Profiles of Alkalophilic and Alkaline-resistant Strains of Actinomycetes
}

\author{
By YUZURU MIKAMI, ${ }^{1 *}$ KIYOTAKA MIYASHITA, ${ }^{2}$ AND \\ TADASHI ARAI ${ }^{-}$ \\ ${ }^{1}$ Department of Antibiotics, Research Institute for Chemobiodynamics, Chiba University, \\ Chiba, Japan \\ ${ }^{2}$ Department of Soil and Fertilizer, National Institute of Agricultural Science, Ibaraki, Japan
}

(Received 18 August 1981: revised 3 February 1982)

Twenty alkalophilic actinomycetes with optimum growth $\mathrm{pH}$ of 9.0 to 9.5 were isolated. Although these new isolates morphologically closely resembled conventional streptomycetes containing LL-diaminopimelic acid, nine out of 20 isolates contained meso-diaminopimelic acid.

Among 420 International Streptomyces Project (ISP) Streptomyces strains tested for their maximum growth $\mathrm{pH}$, only 6 strains grew at $\mathrm{pH} 11 \cdot 5$. Of these six strains, three strains, $S$. caeruleus ISP 5103, A. alborubidus ISP 5465 and $S$. autotrophicus ISP 5011 contained meso-diaminopimelic acid.

\section{INTRODUCTION}

In the classification of Actinomycetales, cell wall composition has become widely accepted as an aid to the differentiation of the genera, in addition to more traditional taxonomic characters (Lechevalier \& Lechevalier, 1970).

Recently, we have isolated alkalophilic actinomycetes from soil as a possible source of new antibiotics. In the course of taxonomic studies of these isolates, it was found that about half of them contained meso-diaminopimelic acid, even though they were morphologically indistinguishable from conventional Streptomyces containing LL-diaminopimelic acid in the cell wall.

Here some characteristics of the newly isolated alkalophilic actinomycetes, as well as those of alkaline-resistant International Streptomyces Project (ISP) Streptomyces strains are described, with emphasis on the cell wall diaminopimelic acid'configuration.

\section{METHODS}

Isolation of alkalophilic actinomycetes from soil. Medium for the isolation of alkalophilic actinomycetes contained ( $\mathrm{g} \mathrm{1}^{-1}$ ): polypeptone (Wakojunyaku, Co., Tokyo, Japan), 10; meat extract (Kyokuto Co., Tokyo, Japan), 10; yeast extract (Difco), 3; glucose, 3; $\mathrm{Na}_{2} \mathrm{CO}_{3}$ (anhydrous), 10; agar (Koso Chemical Co., Tokyo, Japan), $15 ; \mathrm{pH} 10.0$ or 11.0 (after autoclaving). $\mathrm{Na}_{2} \mathrm{CO}_{3}$ or $\mathrm{NaOH}$ were separately sterilized and used for adjusting the $\mathrm{pH}$. Alkalophilic actinomycetes were isolated from the agar medium by plating water suspensions of soil samples from Chiba and Ibaraki prefectures (Japan), and incubating at $27^{\circ} \mathrm{C}$ for one to two weeks.

After primary isolation, growth on media incubated at $27^{\circ} \mathrm{C}$ for one week at $\mathrm{pH} 6.0$ and 11.5 was compared. Isolates unable to grow at $\mathrm{pH} 6.0$, but able to grow at $\mathrm{pH} 11.5$ or above were used in the subsequent experiments.

Determination of alkaline-resistance of ISP Streptomyces strains. A total of 420 ISP strains of Streptomyces (Shirling \& Gottlieb, 1972), maintained in this laboratory or kindly given by Dr A. Seino (Kaken Chemical Co., Tokyo, Japan), were used. Growth at $\mathrm{pH} 6.0$ and 11.5 was checked as above. 
Cell wall analysis. For cell wall analysis, cultures were grown in shake flasks containing $\left(\mathrm{g} 1^{-1}\right)$ : peptone (Difco), 10; meat extract, 10 ; glycerol, $10 ; \mathrm{NaCl}, 8 ; \mathrm{pH} 10.0$ before autoclaving. After incubation in a reciprocal shaker ( $200 \mathrm{rev} . \mathrm{min}^{-1}$ ) at $27^{\circ} \mathrm{C}$ for 78 to $96 \mathrm{~h}$, the cultures were collected by centrifugation, and thoroughly washed with distilled water. The washed mycelia were treated as described by Cummins \& Harris (1958).

The purified cell wall preparation was used for amino acid analysis using an automatic amino acid analyser (Hitachi Seisakujo Co., Japan). For sugar and diaminopimelic acid determination, the washed whole cell preparation was hydrolysed (Becker et al., 1965) and chromatographed on microcrystalline cellulose TLC plates (Avicel SF cellulose, Asahi Kasei Co., Japan). Solvents used were pyridine/ethyl acetate/acetic acid/water $(36: 36: 7: 21$, by vol.) for sugars, and methanol/pyridine/ $\mathrm{HCl}(10 \mathrm{M}) /$ water $(80: 10: 25: 17 \cdot 5$, by vol. $)$ for diaminopimelic acid. After 7 to $8 \mathrm{~h}$ development, the dried chromatograms were sprayed with aniline phthalate and ninhydrin, respectively.

Determination of optimum $\mathrm{pH}$ for growth. The range of $\mathrm{pH}$ allowing optimum growth was determined by the incorporation of $\left[{ }^{3} \mathrm{H}\right]$ adenine into actinomycete cells. The reaction mixture contained $2 \mathrm{ml}$ of the following medium (g ${ }^{-1}$ ): L-asparagine, 1 ; glycerol, $10 ; \mathrm{MgSO}_{4} .7 \mathrm{H}_{2} \mathrm{O}, 0.01 ; \mathrm{CaCl}_{2}, 2 \mathrm{H}_{2} \mathrm{O}, 0.01 ; \mathrm{K}_{2} \mathrm{HPO}_{4}, 0.1 ; 2 \mathrm{ml}$ Good's buffer (Good et al., 1966) at intervals of $1 \mathrm{pH}$ unit in the range $\mathrm{pH} 6.0$ to 11.0 , and $0.2 \mathrm{ml}\left[{ }^{3} \mathrm{H}\right]$ adenine $\left(2 \mu \mathrm{Ci} \mathrm{ml}{ }^{-1}\right.$; $74 \mathrm{kBq}$ ). The reaction was initiated by adding $0.5 \mathrm{ml}$ spore suspension from the organisms grown on oatmeal agar

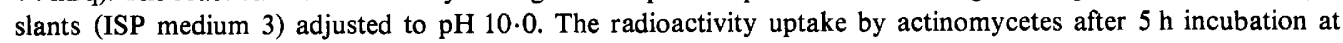
$27^{\circ} \mathrm{C}$, was counted by a Packard Tri-Carb Liquid Scintillation Spectrometer.

Morphological characterization. The morphology of spore chains and spore surface was observed with a Hitachi HU-12 transmission electron microscope, and an Hitachi S-450 scanning electron microscope.

\section{RESULTS AND DISCUSSION}

When newly isolated alkalophilic actinomycetes were compared with reference strains such as Streptomyces lavendulae ISP 5069, S. aureofaciens ISP 5127, S. antibioticus ISP 5234, S. albus ISP 5313, S. hygroscopicus ISP 5578, S. erythraeus ISP 5517 and Streptoverticillium netropsis ISP 5259, clear differences in the optimum growth pH were observed (Fig. 1). The characteristic features of the isolates were good growth in alkaline media, with optimum activity at pH 9.0 to 9.5 , and little or none at $\mathrm{pH} 6.0$ to 7.0 . The growth optimum of most Streptomyces type cultures tested was around $\mathrm{pH} 7 \cdot 0$.

When 420 ISP Streptomyces strains were tested for growth at $\mathrm{pH} 6.0$ and 11.5 , all strains (except for $S$. caeruleus ISP 5103) were able to grow on the medium adjusted to $\mathrm{pH} 6 \cdot 0$, whereas only six strains, S. caeruleus ISP 5103, Actinomyces (Streptomyces) alborubidus ISP 5465, $S$. canescens ISP 5001, $S$. autotrophicus ISP 5011, S. cavourensis ISP 5300, and $S$. hydrogenans ISP 5586, grew at $\mathrm{pH} 11 \cdot 5$. Cell wall analysis of these six ISP streptomycetes revealed that three strains, $S$. caeruleus ISP 5103, Actinomyces alborubidus ISP 5465 and $S$. autotrophicus ISP 5011, had meso-diaminopimelic acid. Therefore it was decided to study the diaminopimelic acid configuration of the alkalophilic and alkaline-resistant isolates.

Analysis of 20 newly isolated alkalophilic actinomycetes revealed that nine strains had meso-diaminopimelic acid. The strains containing LL-diaminopimelic acid had glycine, which is one of the characteristic amino acids of Streptomyces, but no glycine was detected in those containing meso-diaminopimelic acid. No characteristic sugars such as madurose, galactose and arabinose were observed among alkalophilic isolates of actinomycetes containing either LL- or meso-diaminopimelic acid.

All isolates developed abundant aerial mycelium, frequently some shade of blue, purple or yellow in colour.

Nineteen out of 20 strains belonged to the section Rectiflexibiles (Shirling \& Gottlieb, 1966), with smooth spore surface, and the remaining one to the section Retinaculiaperti, also with smooth spore surface.

Taber $(1959,1960)$ first reported 24 strains of 'alkalophilic actinomycetes' as acid-sensitive strains, not growing below pH $6 \cdot 1$ to $6 \cdot 8$. However, no further detailed taxonomic studies on the strains were reported. To our knowledge, only two species, $S$. caeruleus and $S$. alcalophilus, both antibiotic producers, have been shown to be alkalophilic. According to the original description, S. alcalophilus (Yoshida et al., 1979) contained LL-diaminopimelic acid, 


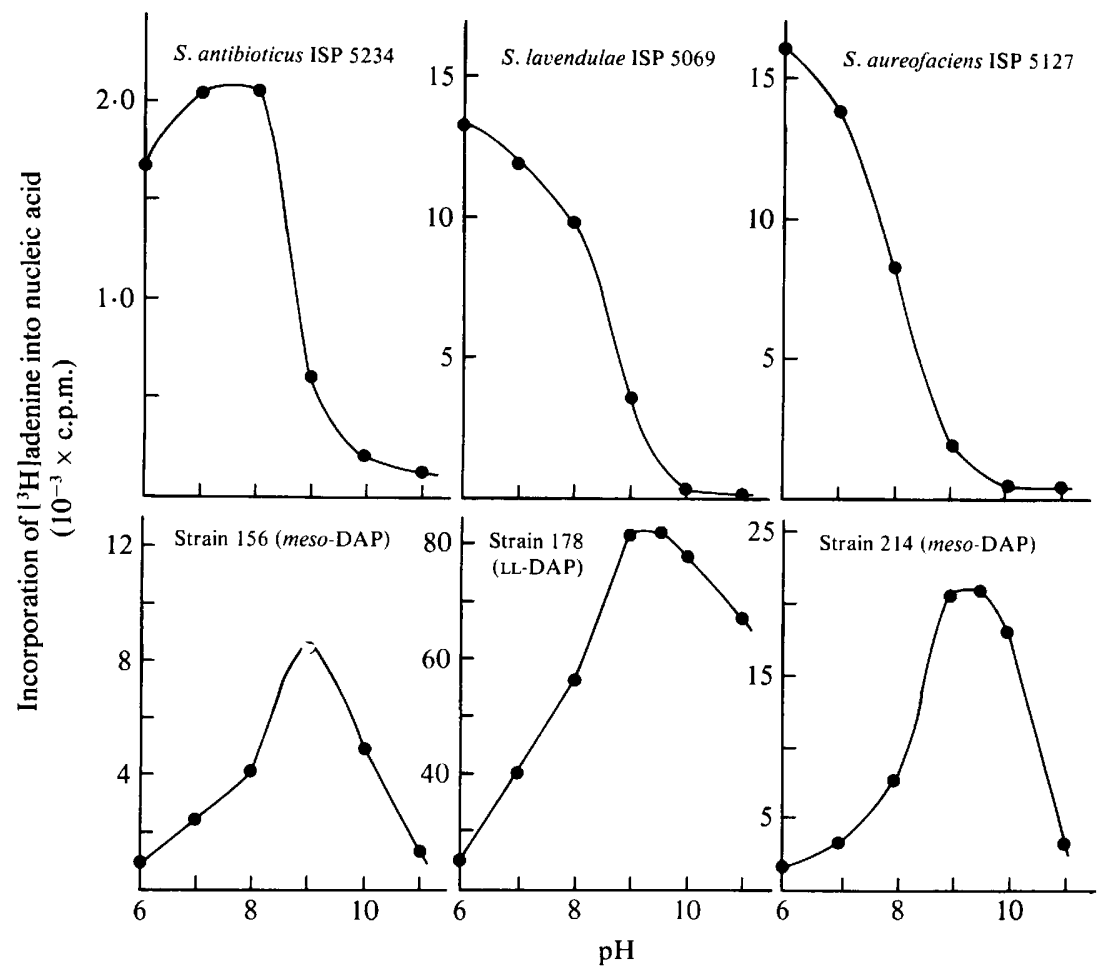

Fig. 1. Incorporation of $\left[{ }^{3} \mathrm{H}\right]$ adenine into three alkalophilic streptomycete strains and three ISP strains of Streptomyces. The type of diaminopimelic acid (DAP) in the cell walls of the alkalophilic isolates is indicated.

and our experiment revealed that $S$. caeruleus contained meso-diaminopimelic acid in the cell wall.

Although several genera such as Streptomyces, Nocardioides, Streptoverticillium, Elytrosporangium, Microellobosporia, Chainia and Sporichthya (Prauser, 1976a, b) have been reported to have cell wall type I (LL-diaminopimelic acid) and to bear aerial mycelium, the alkalophilic isolates with LL-diaminopimelic acid resemble Streptomyces morphologically. On the other hand, the isolates with cell wall type III (meso-diaminopimelic acid and no glycine) showed some similarity to Nocardiopsis (Meyer, 1976).

Studies of the $\mathrm{pH}$ requirements of the alkalophilic isolates and the six ISP Streptomyces strains indicated that they fell into one of two groups. Firstly, there were those which grew well in the range from $\mathrm{pH} 8.0$ to 11.5 with optimum growth around 9.0 to 9.5 ; these could be designated 'alkalophilic actinomycetes'. Secondly, there were strains which grew well around $\mathrm{pH} 7.0$ and still grew at $\mathrm{pH} 11.5$ with an optimum growth $\mathrm{pH}$ around $\mathrm{pH} 7.0$; these could be designated 'alkaline-resistant actinomycetes'. According to this distinction, the new isolates were alkalophilic, while the five ISP strains were alkaline resistant, with the exception of $S$. caeruleus ISP 5103, which grew in the range from $\mathrm{pH} 6.0$ to 11.5 .

Maximum incorporation of adenine across the membrane of alkalophilic actinomycetes occurred between $\mathrm{pH} 9.0$ and 9.5 . This suggested that their membrane may exhibit alkalophilic properties when adenine is used as a substrate.

\section{REFERENCES}

Becker, B., Lechevalier, M. P. \& Lechevalier, H. A. (1965). Chemical composition of cell-wall preparations from strains of various form-genera of aerobic actinomycetes. Applied Microbiology 13, 236-243.

Cummins, C. S. \& Harris, H. (1958). Studies on the 
cell-wall composition and taxonomy of Actinomycetales and related groups. Journal of General Microbiology 18, 173-189.

Good, N. E., Winget, G. D., Winter, W. \& ConNolly, T. N. (1966). Hydrogen ion buffers for biological research. Biochemistry 5, 467-477.

LechevalieR, M. P. \& LechevalieR, H. A. (1970). Chemical composition as a criterion in the classification of aerobic actinomycetes. International Journal of Systematic Bacteriology 20, 435-443.

MEYER, I. (1976). Nocardiopsis, a new genus of the order Actinomycetales. International Journal of Systematic Bacteriology 26, 487-493.

Prauser, H: (1976a). New nocardioform organisms and their relationship. In Actinomycetes: The Boundary Microorganisms, pp. 193-207. Edited by T. Arai. Tokyo: Toppan Co.

Prauser, H. (1976 b). Nocardioides, a new genus of the order Actinomycetales. International Journal of Systematic Bacteriology 26, 58-65.
Shirling, E. B. \& GotTlieb, D. (1966). Methods for characterization of Streptomyces species. International Journal of Systematic Bacteriology 16, 313-340.

Shirling, E. B. \& Gotrlieb, D. (1972). Cooperative description of type strains of Streptomyces. V. Additional descriptions. International Journal of Systematic Bacteriology 22, 265-394.

TABER, W. A. (1959). Identification of an alkalinedependent Streptomyces as Streptomyces caeruleus Baldacci and characterization of the species under controlled conditions. Canadian Journal of Microbiology 5, 335-344.

TABER, W. A. (1960). Evidence for the existence of acid-sensitive actinomycetes in soil. Canadian Journal of Microbiology 6, 503-514.

Yoshida, K., Iguchi, A., Mukaisaka, M., AokI, H. \& IMANAKA, H. (1979). Japan Patent 151196, November 28. 